\title{
Chapter 5 \\ Towards Energy-Efficient Machine Tools Through the Development of the Twin-Control Energy Efficiency Module
}

\author{
Dominik Flum, Johannes Sossenheimer, Christian Stück \\ and Eberhard Abele
}

\subsection{Introduction}

Energy efficiency issues have played an increasingly important role in society, business and politics in recent years. Above all, noticeable environmental impacts are one reason for this. This increases customer awareness and introduces additional legal regulations. As a very large proportion of global primary energy demand is caused by the manufacturing industry, this represents a great lever for reducing energy demand and the associated emissions [1]. Furthermore, energy is an increasingly important cost factor. This results in high customer demand for energy-efficient machines.

Studies have shown that $26 \%$ of operating costs of a machine tool are caused by energy costs for machine tools-excluding labour, tooling and material costs [2]. As energy prices continue to rise in the foreseeable future, the importance of the energy efficiency factor will play a greater role alongside the classic dimensions of precision, performance and reliability $[3,4]$.

D. Flum $(\bowtie) \cdot$ J. Sossenheimer · C. Stück · E. Abele PTW TU Darmstadt, Darmstadt, Germany

e-mail: d.flum@ptw.tu-darmstadt.de

J. Sossenheimer

e-mail: j.sossenheimer@ptw.tu-darmstadt.de

C. Stück

e-mail: info@ptw.tu-darmstadt.de

E. Abele

e-mail: info@ptw.tu-darmstadt.de

(C) The Author(s) 2019

M. Armendia et al. (eds.), Twin-Control,

https://doi.org/10.1007/978-3-030-02203-7_5 


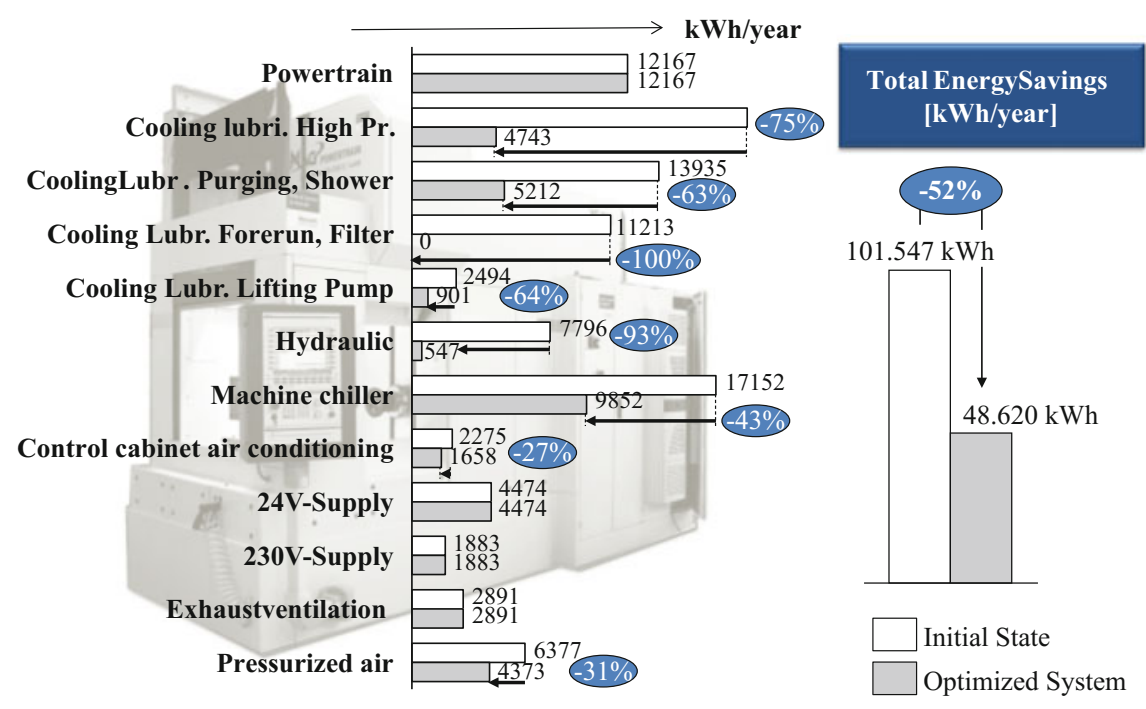

Fig. 5.1 Realized energy-saving measures on a machine tool of the type MAG XS211 [5]

\subsubsection{Energy Efficiency of Production Machines}

Many different approaches to increasing energy efficiency in production technology have already been investigated. One example of this is the research project "Maxiem-maximizing the energy efficiency of machine tools". The project results show the potential and possibilities with regard to energy efficiency optimization in machine tools. Various measures for component-oriented optimization and evaluation of energy efficiency were carried out using a MAG XS 211 four-axis machining centre as an example. By analysing the energy consumption of individual components, the actual delivery status of the machining centre was determined. Most of the energy was consumed by the machine cooling system, the cooling lubricant system and the hydraulic system. Based on the assumption of mass production with a threeshift operation and six working days per week, $50 \%$ of the energy could be saved through the use of an energy-optimized configuration (Fig. 5.1) [5].

\subsubsection{Scope of Investigation}

The measures to optimize the energy efficiency of metal-cutting machine tools are manifold. The optimization measures can generally be classified according to the overview in Fig. 5.2. According to this, an increase in the energy efficiency of machine tools can be achieved by [6]: 


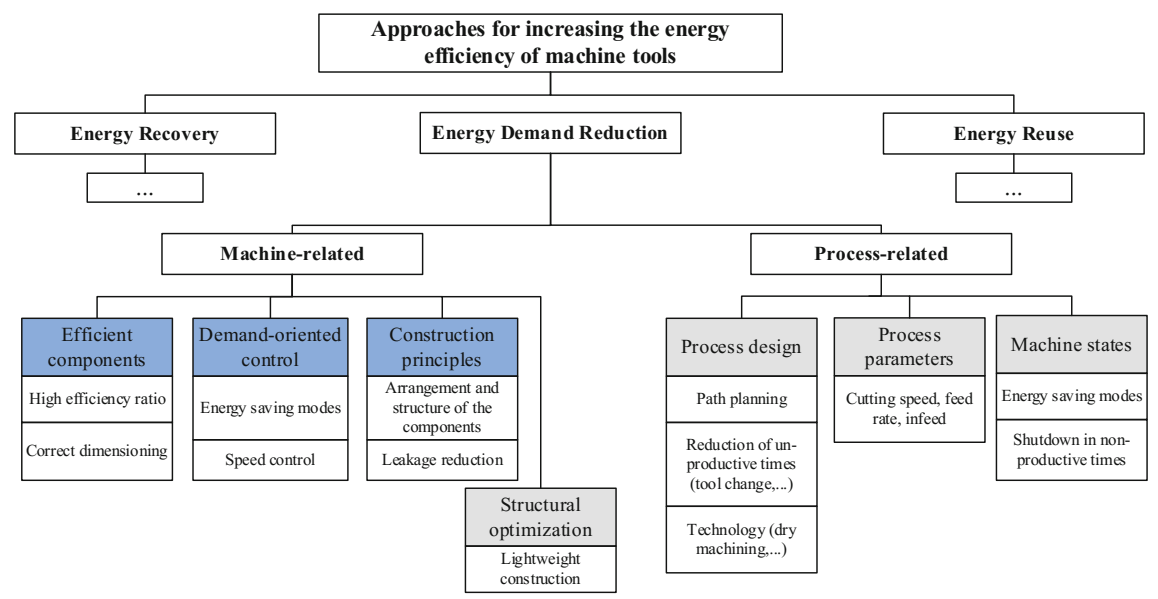

Fig. 5.2 Investigated approaches to increase energy efficiency (marked in blue) (see [3])

- Recovery of the energy used,

- Reuse of energy,

- Reduction of energy demand.

The research activities in the Twin-Control project focused on reducing the energy demand. This is basically the key step in optimizing energy efficiency, as it also reduces the energy loss such as waste heat. The measures used are not intended to influence the productivity of the machining process. Therefore, the optimization of the machine tool itself was investigated. Starting points in general are [6, 7]:

- Use of efficient components with higher efficiency,

- Implementation a demand-oriented control by (partially) switching off modules when not in use,

- Design of the machine modules by applying energy-efficient construction principles.

When considering the design of the assemblies, oversizing and "safety surcharges" that are frequently encountered, especially when designing pumps and motors, should be avoided. This results in the components no longer running at their optimum operating point, which in turn has a negative effect on energy efficiency [7].

Standby operation, which means switching off or activating an energy-saving mode for modules or components when they are not in use, also reduces the energy consumption of metal-cutting machine tools [8]. This is achieved, for example, by implementing energy management functions on the machine control whereby certain modules are switched off either after a time defined by the user or after completion of the part program [9].

Due to different operating states and varying process parameters, such as tool change, spindle speed and feed rate, different types and frequencies of loads act on the machine tool assemblies. The operation of the components can be adapted to the 
different performance requirements by process-adapted and demand-oriented control of motors and pumps by means of speed control using a frequency converter. Often pumps in machine tools are operated at mostly constant speed whereby the flow rate is adapted to the current demand by a throttle or bypass control [7, 10]. In load cases where a component is operated at a constant operating point, speed control is energetically disadvantageous. The efficiency losses of the frequency inverter during speed control would lead to deterioration in energy efficiency [11]. A further optimization option is the use of efficient components with improved efficiency. Examples of components with high energy-saving potential are pumps, electric motors or cooling units [7].

\subsection{Theoretical Background}

Existing scientific approaches for both approximation and simulation of the energy requirements of machines and production processes are presented below.

\subsubsection{Machine Simulation and Process Modelling}

Reeber [12] developed an approach in the field of cutting machine tools that enables the calculation of the specific cutting energy. The basis is an empirical model of cutting force developed by [13]. This makes it possible to determine the cutting force depending on different material and process parameters [12, 13]. The calculations only take into account the energy required for the cutting process, not the total energy consumption of the machine [3].

Degner and Wolfram [14] presented an approach that complements the approach of [12] to the additional energy demand of the machine tool. For this purpose, electrical measurements of reactive power in the air cut formed the basis (all units enabled, no tool contact) [3, 14-18].

A first observation of the energy consumption of a machine tool in non-production times was made by [19]. His assumption was constant power consumption with stationary machine axes [19].

Another similar approach was developed by Gutowski et al. [20]. This is based on electrical power measurements on various machine tools. The energy demand of the process-specific component is calculated from a base load and the process load. The machining load was determined by various milling tests with different removal rates, while the base load is assumed to be constant $[20,21]$.

Draganescu et al. [22] evaluate the energy efficiency of machine tools by analysing the energy effectiveness, which is defined as the ratio of theoretical cutting energy to total energy demand. Using statistical methods and empirical data, a mathematical model was developed that maps the ratio of different operating parameters, such 
as torque, feed rate and spindle speed in order to approximate the specific power consumption of a machine tool [22, 23].

Dietmair et al. [24] used an empirical model based on graph theory to predict the energy demand of cutting machine tools. A specific electrical power demand was set for each machine component according to the current machine mode. If the duration and the order of the individual machine modes are specified, the power consumption and the energy demand of the individual components can be determined. The result is the energy demand of the entire machine [3, 24-27].

The approach of [24] was extended by [28]. He assigned a certain power and time demand to the transition between different machine modes. However, both approaches neglect dynamic effects. Each machine mode is assigned to a single power consumption [28].

Schrems [29] developed an approach based on a dynamic simulation to predict the energy demand of various production processes and machines. For this purpose, production machines contained in a process chain are represented by generic models. Datasheet information is used to parameterizing the models that can be used to determine the energy demand of certain configurations. Eventually, the energy demand can be taken into account when planning process chains and selecting alternative production machines [29].

\subsubsection{Energy Demand Approximation of Production Machines}

Kuhrke [7] developed a methodology for a prospective assessment of the medium and energy demand that can already be used in the offer phase of machine tools. Therefore, a foundation for machine tool manufacturers, as well as for operators for a coherent evaluation of the energy and medium demand, is provided. The basis for this is the analysis of a sample machine, in which he developed calculation rules for each energy-relevant component. This was based on information from datasheets and data gained by measurements if the required information in the datasheets was insufficient. Finally, by aggregating the individual demands, the total energy consumption of the machine tool can be calculated [7].

Another approach emerges from Bittencourt [30]. He presented a prediction model for the energy demand of machine tools. Electrical power measurements on different modules under different operating conditions of the production machine serve as a basis. For modules with process-dependent power consumption, further test series were carried out under various load conditions. Subsequently, a characteristic curve model was developed using spline curves, which enables the calculation of energy consumption depending on the production task [30]. 


\subsubsection{Summary}

In contrast to many of the previous work, the approach presented below is not dependent on energy measurements on existing production machines. On the one hand, electrical power measurements are often unsuitable in a production environment because they are associated with increased effort and high costs, as the execution of the measurements is time-consuming, and production may have to be stopped. In addition, measurements cannot usually be used in the planning phase of a product or production due to a lack of physical components. The energy efficiency module of Twin-Control, however, supports the machine design by dimensioning and selecting components according to the prevailing needs using mainly datasheet information.

\subsection{The Energy Efficiency Module}

The energy efficiency module of Twin-Control aims to support machine tool builders within the machine design phase to choose an energetically optimal machine configuration. In addition, the simulation tool enables part manufacturers to guarantee an energy-efficient part production considering different NC Code alternatives. For establishing energy efficiency measures, a machine tool builder or user needs, in the first place, information about the possible energy efficiency measures. Secondly, a systematic and transparent decision-making process is necessary to evaluate several energy efficiency measures. These prerequisites will be accomplished by the energy efficiency module.

\subsubsection{Framework}

The energy efficiency module is intended to act as a platform between developers and users in order to promote the implementation of energy efficiency solutions through increased transparency of the energy demand.

The core of the energy efficiency module is the simulation models. Those models are established in the simulation software MATLAB/Simscape and will be discussed in Chap. 4. For parameterizing the simulation models, input from machine tool user and machine tool builder is employed. Hardware information needs to be provided, especially by the machine tool builder. This information is used to parameterize the developed component simulation models to a specific machine tool. The energy demand of a machine tool, however, is not only determined by its hardware but also by its production task. The production task can be divided into three dimensions (Fig. 5.3). 


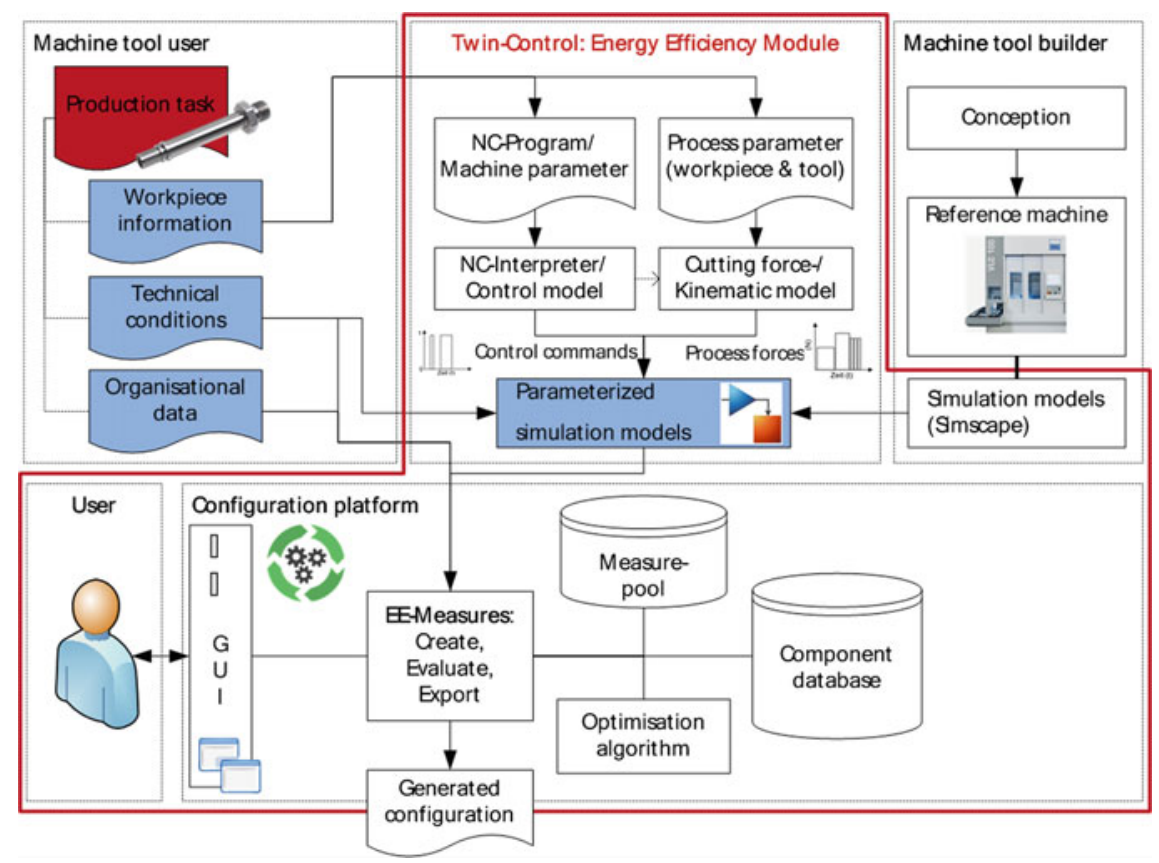

Fig. 5.3 Framework of the energy efficiency module

- Workpiece information: the component information includes the part to be produced, which is described by the NC program and related information, such as material and tool parameters.

- Technical conditions: this includes a variety of technical information.

- Production environment: ambient conditions (temperature, vibration, etc.).

- Technological requirements: required production processes, flexibility of machine, quality requirements.

- Infrastructure: options to subscribe for compressed air, existing cooling/filtration systems, energy networks in buildings and other production machines and chip removal.

- Organizational data: The organizational data include company-specific information to the parent production environment, which go beyond the technical information. These include, inter alia, production hours per year, the price of electricity and the basic proportions of the machine conditions (production, standby, off). These data form the basis of the balance between energy efficiency and cost aspects.

The design of the energy efficiency module follows a tripartite model-viewcontroller (MVC) approach with the following features.

- Module database: the modules are held in the form of strategies for energy efficiency measures. 
- Configuration algorithm: the algorithm creates configurations based on modules. The creation and review are automated.

- Input and output mask: visualization supports the configuration process.

\subsubsection{Key Elements}

The key elements of the energy efficiency module are briefly described below. Since the energy simulation models make up the essential part, they are discussed separately in this chapter.

- Energy efficiency measure pool: the basic approaches to energy efficiency improvements are collected in a measure pool. These approaches represent templates for energy efficiency measures that can be taken into account for the configuration.

- Measure creation: To apply an energy efficiency measure, it must first be created or configured. Since measures can only be performed on the basis of an existing basic configuration, it is important to create them if they do not exist as intended. During measure creation, the templates from the energy efficiency measure pool are linked to the conditions and requirements defined by the machine tool user. For individual measures, components are pre-selected from a database, which then represent configuration alternatives. This enables the optimization algorithm to perform an action automatically. If a measure is to be applied to several machine assemblies, it is created separately for each assembly. Assemblies that are not considered are initially treated as black boxes, which can be detailed by additional measures.

- Component database: the component database includes a plurality of components of different types. For each component, the required information such as datasheet specifications and list prices are stored. Since the creation of the database is associated with a comparatively high cost, it is created project and machine independent and is permanently available.

- Optimization algorithm: the optimization algorithm performs a measure by using mathematical optimization methods and a system of rules for an automated selection of a suitable configuration. An essential component is the quantitative review of alternatives as a guide for the selection. The alternative with the best value is then added to the project.

- Energy efficiency project: the project is a collection of already defined measures and thus shows the current configuration status. In order to offer the user control and modification possibilities of the optimization algorithm, there is a detailed view of existing measures.

- Configuration result: The generated configuration is a collection of measures. To make them available outside the platform, they must first be prepared. This includes, e.g. a collection of parts lists or datasheets based on the selected alter- 


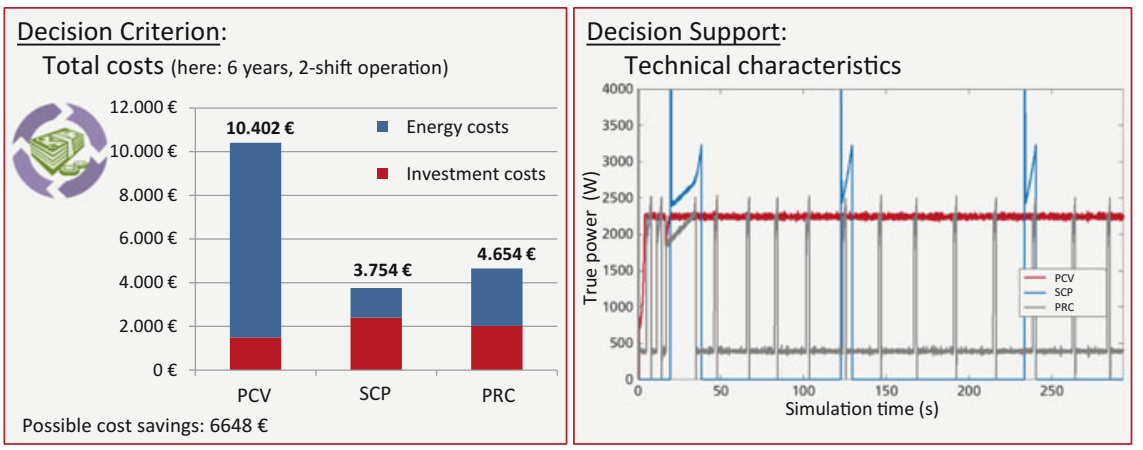

Fig. 5.4 Exemplary results of the configuration platform

natives. There should be an additional check of the configuration by an expert staff.

- Graphical user interface (GUI): a graphical user interface guides the operator in using the configuration platform. The elements, such as measure creation and solution selection are provided with dialogues, through which the user can perform inputs.

An exemplary application of the configuration platform is shown in Fig. 5.4, in which three different configuration options for a hydraulic system are compared. Basically, the three marketable variants are a pressure control valve (PCV), a speed controlled pump (SCP) and a pressure reduced circulation (PRC). Using an optimized configuration allows possible cost savings of up to $6648 €$ under the assumption of an investigation period of 6 years and a two-shift operation.

\subsection{Energy Simulation of Machine Tools}

A popular approach in order to predict the behaviour of production machines is the use of simulation models. According to [31], simulation can generally be applied for technical systems within every lifecycle phase: during product development, the predicted system behaviour can be verified; in the use phase, potential changes to the utilization profile or retrofit measures can be evaluated in advance [23, 31]. In order to forecast and simulate the energy consumption of machine tools, dynamic models of various components were set up. Those models represent the core of the configuration platform (Fig. 5.3). Through modelling all components relevant to the energy demand and the energetic interconnectivity, all functional modules of a production machine are set up. Besides electrical energy, all other energy types are taken into account influencing the electric behaviour (e.g. hydraulic and mechanical energy). The simulation model is implemented within the software environment MATLAB/Simscape. 


\subsubsection{Basic Principle}

The presented simulation approach covers the relevant mechanisms for calculating the energy demand of production machines. In general, the simulation structure distinguishes between three model layers (compare to Fig. 5.5) [3]:

\section{Process Layer (NC Code Interpreter)}

Within the process layer, the interaction between the workpiece and the tool is mapped. Cutting force calculations, as well as tool engagement estimations, are performed in this part of the simulation model. Through transforming the calculated cutting forces into torque on the main spindle as well as forces on the feed drives, the load on the drive system of the production machine can be predicted.

\section{Machine Layer (Machine Simulation)}

Every functional module relevant to the energy demand of a production machine is mapped in the machine layer. Depending on the available datasheet information of the component manufacturer, physical/mathematical interrelationships and characteristic curves/maps are used for setting up the simulation models. Besides fixed component parameters, the model behaviour depends on dynamic interactions on functional module level, process-dependent loads from the process layer and control commands generated by the control layer.

\section{Control Layer (Model Control)}

The control layer represents the physical machine control of a production machine. Using input data of the process layer, speed for feed and spindle drives, as well as switching information of peripheral systems, are provided for the machine layer.

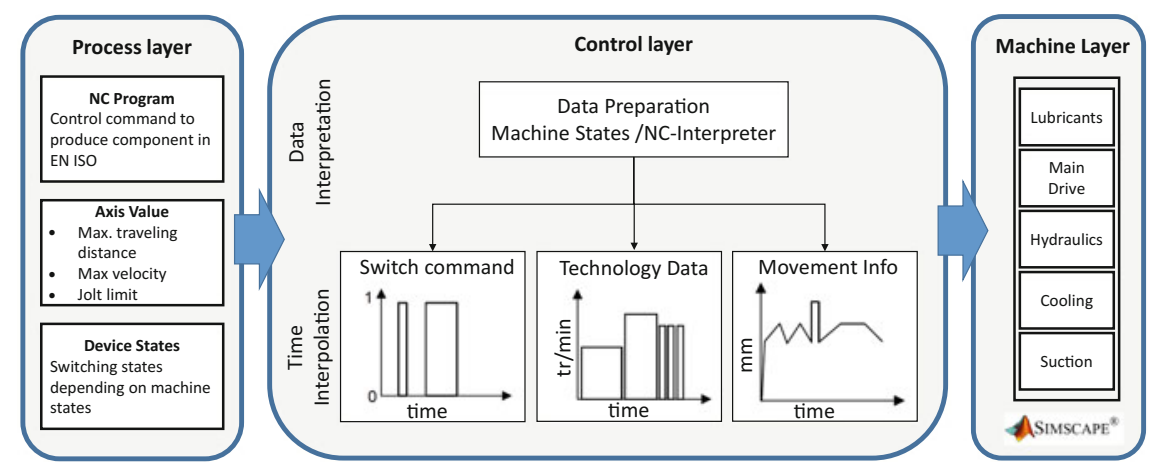

Fig. 5.5 Basic concept of the (physical) energy simulation models (see [3]) 


\subsubsection{Modelling the Machine Tool Components}

The simulation models are implemented within the software environment MATLAB/Simscape. It is an extension for Simulink, which makes an object-oriented modelling of physical systems possible. Unlike Simulink, physical components can be modelled using a Simscape-specific programming language. There are already some libraries of basic building blocks, such as electrical resistors. Since they can only be used to a limited extent for the purpose of the project, own components have been developed.

With the help of this library, machine assemblies can be easily mapped. Manufacturer information such as fluid or electrical plans is used for this purpose. The parameterization of the component models is carried out via datasheets. This results in a simple adaptability to different applications (Fig. 5.6).

A concrete model is built up from the individual components, which are taken from the Twin-Control library and then linked to each other. It is possible to orientate
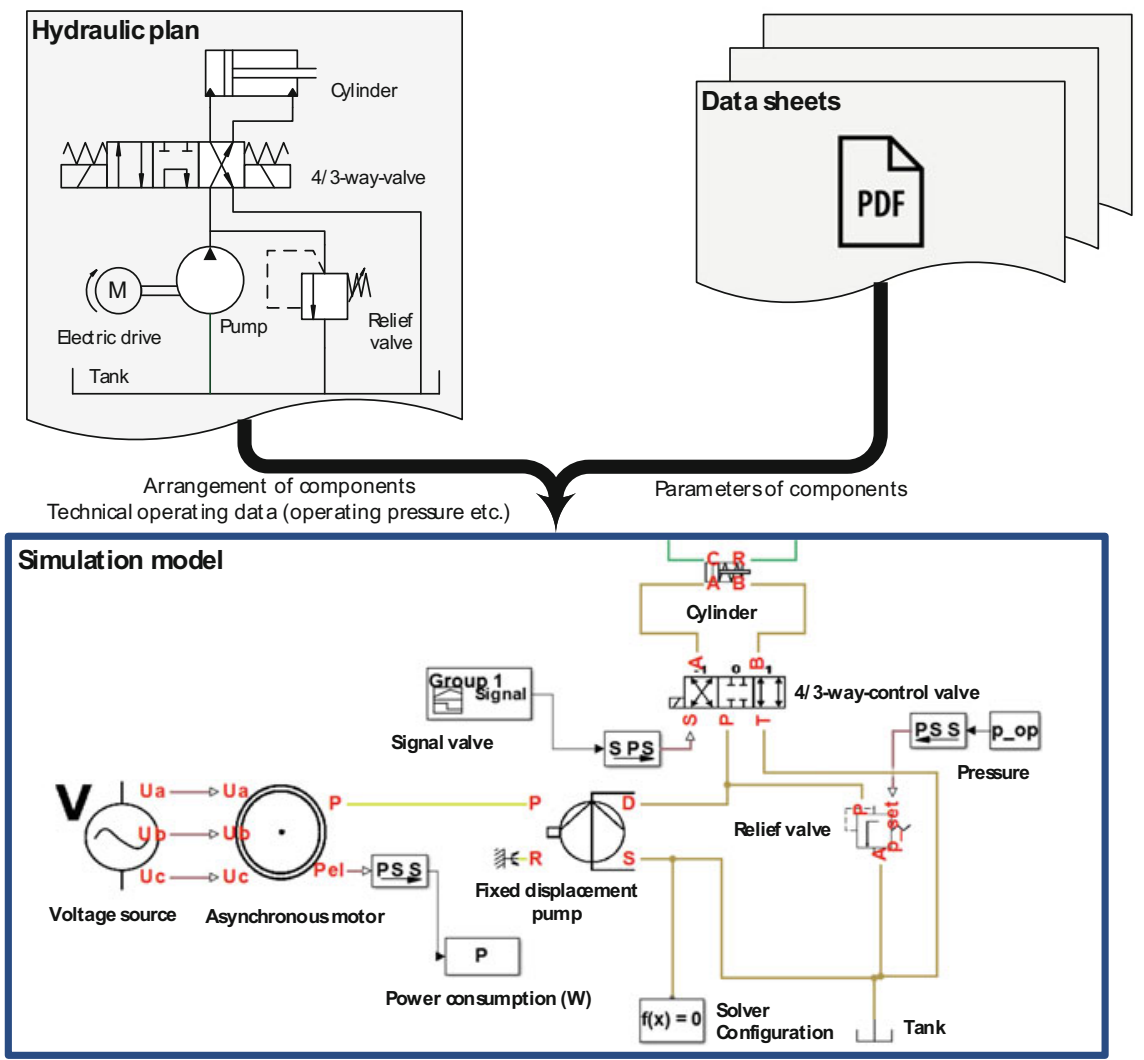

Fig. 5.6 Method of modelling using the example of a hydraulic system (schematic) 


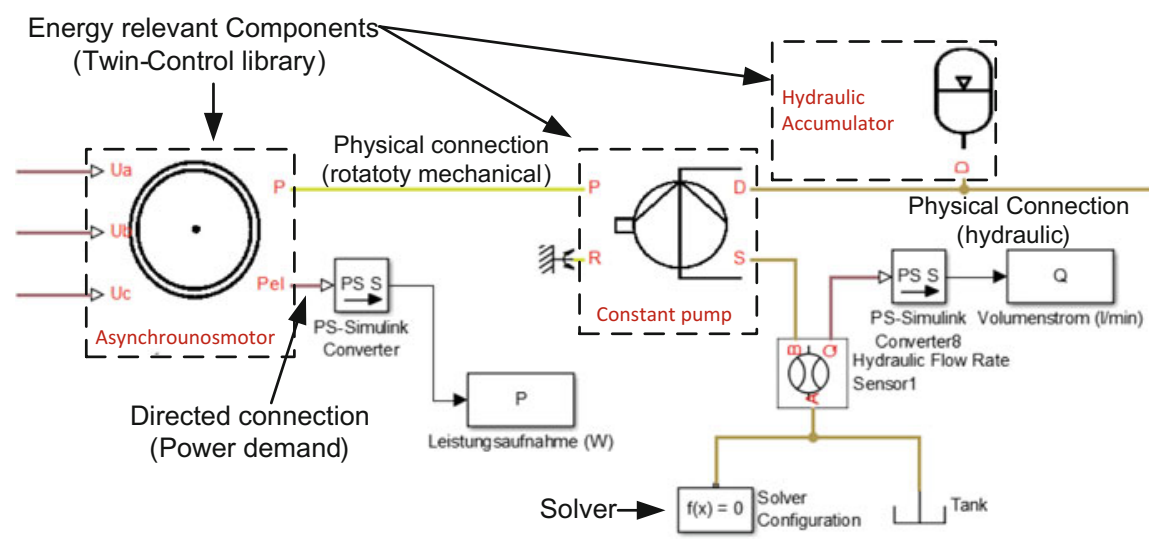

Fig. 5.7 Elements of a model with the methodology used by the example of a hydraulic system

oneself on the "real" machine, e.g. using the fluid diagram of the machine to be mapped. Generally, all required input data can be obtained from datasheets and the NC program. Measurements are not required.

The individual blocks are interconnected by means of non-directional physical connections to a network. The connections are in a physical domain (e.g. mechanics or hydraulics), which can also be recognized by the colour of the connection. In addition, there are directed physical connections (signals) which are used, for example, to reuse individual physical quantities outside the network. Each network also contains a solver block. In addition, all Simulink blocks can be used in the same model. For a connection with the Simscape blocks, their signal must be converted using a special "converter" block (Fig. 5.7).

Using this modelling approach, the level of detail is particularly high and allows the technical behaviour to be checked down to individual parts (valves, pumps, etc.). All energy-relevant assemblies can be modelled, including the drivetrain with dynamic effects.

\subsection{Implementation on EMAG VLC100Y Turning Machine}

As an exemplary application, the modelling and simulation of an EMAG VLC100Y turning machine are presented in this chapter. The machine is part of the Twin-Control pilot line ETA Factory. To validate the models, the electrical power consumption was measured and compared with the simulated values (Fig. 5.8).

For the measurements, a mobile measurement device was used. It consists of three measuring cases which are either connected via LAN or WiFi. With each case, it is possible to measure four consumers. The machining process of the use case consists 


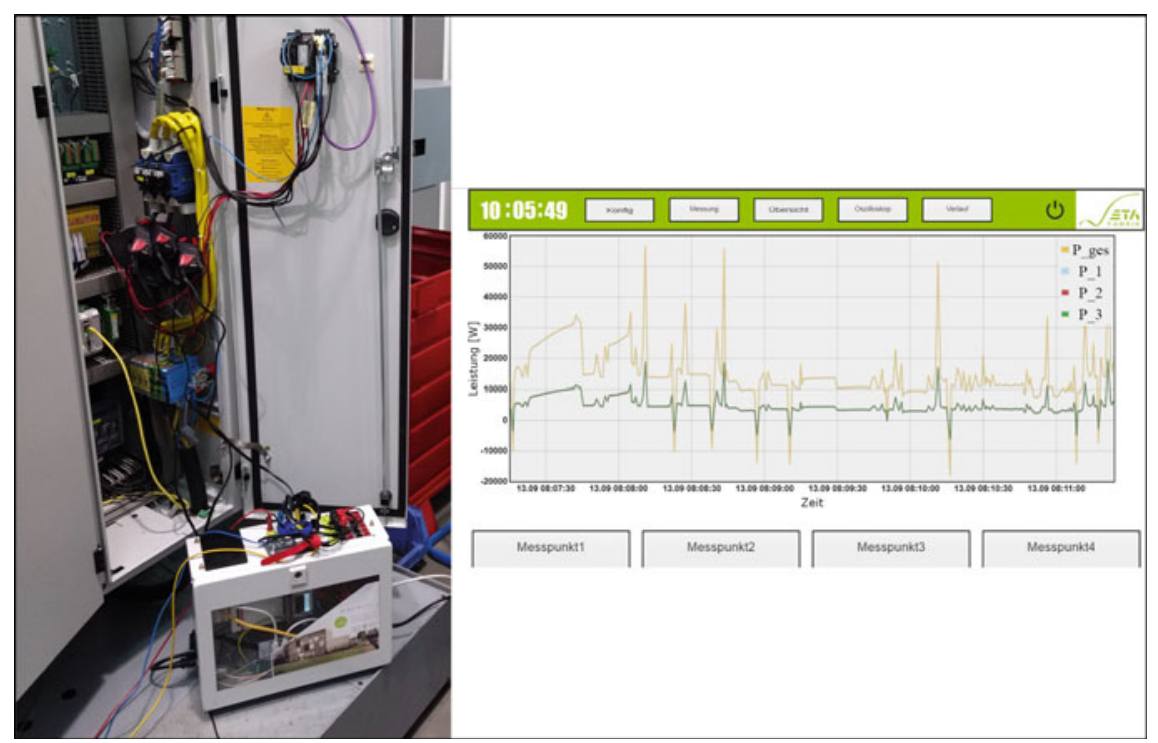

Fig. 5.8 Electric Power Measurement with mobile measurements device on the EMAG VLC 100Y turning machine

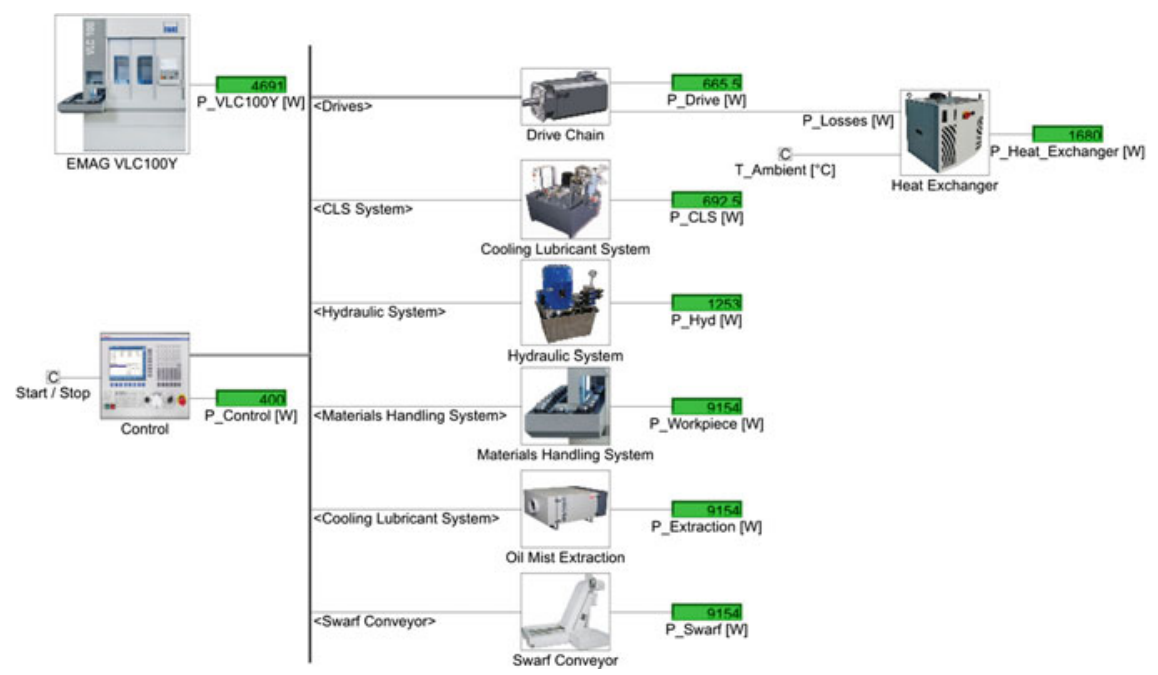

Fig. 5.9 Simulation models with energy-relevant subsystems of EMAG VLC100Y

of two sub-processes (OP10 and OP20). Further, the power consumption in standby and operational was considered (Fig. 5.9).

For a comparison of measurement and simulation data see Table 5.1. Here, the average power consumption in the different machine states is displayed. Especially 
Table 5.1 Comparison of measurement and simulation data

\begin{tabular}{l|l|l|l|l|l|l}
\hline & $\begin{array}{l}\text { Standby } \\
\text { measure- } \\
\text { ment } \varnothing \\
{[\mathrm{W}]}\end{array}$ & $\begin{array}{l}\text { Standby } \\
\text { simulation } \\
\varnothing[\mathrm{W}]\end{array}$ & $\begin{array}{l}\text { Ready mea- } \\
\text { surement } \varnothing \\
{[\mathrm{W}]}\end{array}$ & $\begin{array}{l}\text { Ready } \\
\text { simulation } \\
\varnothing[\mathrm{W}]\end{array}$ & $\begin{array}{l}\text { Work mea- } \\
\text { surement } \varnothing \\
{[\mathrm{W}]}\end{array}$ & $\begin{array}{l}\text { Work } \\
\text { simulation } \\
\varnothing[\mathrm{W}]\end{array}$ \\
\hline $\begin{array}{l}\text { Main } \\
\text { connection } \\
\text { (machine) }\end{array}$ & 443 & 438 & 3292 & 3283 & 6069 & 5911 \\
\hline Drive units & 0 & 0 & 485 & 472 & 1669 & 1509 \\
\hline $\begin{array}{l}\text { Cooling } \\
\text { unit }\end{array}$ & 0 & 0 & 1560 & 1405 & 1560 & 1405 \\
\hline $\begin{array}{l}\text { Hydraulic } \\
\text { pump }\end{array}$ & 0 & 0 & 411 & 430 & 433 & 475 \\
\hline CL pump & 0 & 0 & 0 & 0 & 1313 & 1461 \\
\hline $\begin{array}{l}\text { Chip } \\
\text { Conveyor }\end{array}$ & 0 & 0 & 0 & 0 & 82 & 80 \\
\hline Suction & 0 & 0 & 0 & 0 & 99 & 105 \\
\hline Others & 443 & 438 & 836 & 876 & 913 & 876 \\
\hline
\end{tabular}

for consumers with a more constant power consumption (e.g. chip conveyor and suction), the predicted values are quite close to the measurement data. For components with a more dynamic behaviour like the drive units, the deviation is a bit higher. However, the maximum deviation for the average power consumption is less than $10 \%$. As a result, the applicability of the simulation models for predicting the energy consumption in planning phases could be demonstrated.

\subsection{Conclusions}

The energy demand of machine tools is largely determined in the development phase. This is why the largest levers for increasing energy efficiency are located here. The energy efficiency module of Twin-Control was developed as a planning tool for implementing energy-efficient machine tool configurations. The development of simulation models of all energy-relevant components creates the necessary transparency regarding the energy demand. By coupling with an optimization algorithm, the module automatically searches for the cost optimal configuration under the specified boundary conditions and restrictions. In addition to the investment costs of the components used, the energy costs for the prevailing electricity price are determined from the simulation. A graphical user interface ensures a high user friendliness by allowing user input to be made and results to be evaluated without having to go deeper into the simulation models.

The implementation of the simulation in the pilot line ETA Factory showed that a forecast of the energy demand is feasible with the presented approach. 


\section{References}

1. IEA International Energy Agency: Worldwide Trends in Energy Use and Efficiency. IEA Publications, Paris (2008)

2. Abele, E., Dervisopoulos, M., Kuhrke, B.: Bedeutung und Anwendung von Lebenszyklusanalysen bei Werkzeugmaschinen. In: Schweiger, S. (ed.) Lebenszykluskosten optimieren. Gabler, Wiesbaden (2009)

3. Eisele, C.: Simulationsgestützte Optimierung des elektrischen Energiebedarfs spanender Werkzeugmaschinen. Shaker Verlag, Aachen (2014)

4. BDEW Bundesverband der Energie- und Wasserwirtschaft.: Energiewirtschaftliche Entwicklung in Deutschland. 1. Quartal 2013, Berlin (2013)

5. Abele, E., Sielaff, T., Beck, M.: Konfiguration energieeffizienter Werkzeugmaschinen. In: Werkstattstechnik online: wt, vol. 102, pp. 292-298 (2012)

6. Zein, A., Li, W., Kara, S.: Energy efficiency measures for the design and operation of machine tools: an axiomatic approach. In: Hesselbach, J. (ed.) Glocalized Solutions for Sustainability in Manufacturing. Proceedings of the 18th CIRP International Conference on Life Cycle Engineering, pp. 274-279 (2011)

7. Kuhrke, B.: Methode zur Energie- und Medienbedarfsbewertung spanender Werkzeugmaschinen. epubli, Berlin (2011)

8. Zäh, A., Niehuis, K.: Wieviel Energie verbraucht eine Werkzeugmaschine? In: fertigung. Das Fachmagazin für die Metallverarbeitung, pp. 30-32 (2009)

9. Denkena, B., Garber, B. (ed.).: NC-Plus. Prozess- und wertschöpfungsorientiert gesteuerte Werkzeugmaschine; Final report. PZH-Verl; TEWISS - Technik-und-Wissen-GmbH, Garbsen (2013)

10. Gontermann, D.: Drehzahlregelung reduziert Energiekosten und steigert die Betriebssicherheit. MM Maschinenmarkt 38-41 (2007)

11. de Keulenaer, H., et al.: Sparsame elektrische Antriebe (2004)

12. Reeber, R.: Der Energiebedarf bei trennenden Fertigungsverfahren. Werkstatt und Betrieb 113, 109-113 (1980)

13. Kienzle, O., Victor, H.: Spezifische Schnittkräfte bei der Metallbearbeitung. Werkstofftechnik und Maschinenbau 47, 224-225 (1957)

14. Degner, W., Wolfram, F.: Richtwerte und Regeln für den Energieaufwand bei spanender Fertigung. Fertigungstechnik und Betrieb 33, 739-742 (1983)

15. Degner, W., Herfurth, K.: Energieaufwand bei spanender Teilefertigung. Fertigungstechnik und Betrieb 33, 684-687 (1983)

16. Degner, W., Resch, R., Wolfram, F.: Energieaufwand spanender Fertigungsverfahren und das Prinzip der vergegenständlichten Energie in der Teilefertigung. Metallverarbeitung 83, 132-134 (1984)

17. Wolfram, F.: Aspekte der energetischen Bewertung von Produkten und Prozessen der Abtrenntechnik nach dem Prinzip der vergegenständlichen Energie. Dissertation, Karl-Marx-Stadt (1986)

18. Wolfram, F.: Energetische produktbezogene Bewertung von Fertigungsprozessen. Dissertation, Chemnitz (1990)

19. Schiefer, E.: Ökologische Bilanzierung von Bauteilen für die Entwicklung umweltgerechter Produkte am Beispiel spanender Fertigungsverfahren. Darmstädter Forschungsberichte für Konstruktion und Fertigung (2001)

20. Gutowski, T., Dahmus, J., Thiriez, A.: Electrical energy requirements for manufacturing processes. In: The International Academy for Production Engineering (CIRP) (Hrsg.) Proceedings of the 13th CIRP International Conference on Life Cycle Engineering, pp. 623-627 (2006)

21. Gutowski, T., et al.: A thermodynamic characterization of manufacturing processes. In: International Association of electronics recyclers (Hrsg.) Proceedings of the 2007 IEEE International Symposium on Electronics \& Environment, pp. 137-142 (2007)

22. Draganescu, F., Gheorghe, M., Doicin, C.: Models of machine tool efficiency and specific consumed energy. J. Mater. Proc. Technol. 141, 9-15 (2003) 
23. Abele, E., Braun, S., Schraml, P.: Holistic simulation environment for energy consumption prediction of machine tools. In: 22nd CIRP Conference on Life Cycle Engineering in Sydney, Australia, 7-9 April 2015

24. Dietmair, A.: Energy consumption assessment and optimisation in the design and use phase of machine tools. In: The International Academy for Production Engineering (CIRP) (ed.) Proceedings of the 17th CIRP International Conference on Life Cycle Engineering (2010)

25. Dietmair, A., Verl, A., Wosnik, M.: Zustandsbasierte Energieverbrauchsprofile - Eine Methode zur effizienten Erfassung des Energieverbrauchs von Produktionsmaschinen. In: wt Werkstattstechnik online, vol. 98, pp. 640-645 (2008)

26. Dietmair, A., Verl, A.: Energy consumption forecasting and optimisation for tool machines. Mod. Mach. (MM) Sci. J. 4 (2009)

27. Dietmair, A., Verl, A., Huf, A.: Automatisierung spart Energie - Direkte und indirekte Maßnahmen in der Gerätetechnik. In: Energy 2.0, p. 26 (2009)

28. Bittencourt, J.L.: Selbstoptimierende und bedarfsgerechte Steuerungsstrategien für Werkzeugmaschinen zur Steigerung der Energieeffizienz. Apprimus, Aachen (2013)

29. Schrems, S.: Methode zur modellbasierten Integration des maschinenbezogenen Energiebedarfs in die Produktionsplanung. Shaker Verlag, Aachen (2014)

30. Rief, M.: Vorhersagemodell für den Energiebedarf bei der spanenden Bearbeitung für eine energieeffiziente Prozessgestaltung. Shaker, Aachen (2012)

31. VDI Verein Deutscher Ingenieure: Simulation von Logistik-, Materialfluss- und Produktionssystemen(3633). Beuth Verlag GmbH, Berlin (2013)

Open Access This chapter is licensed under the terms of the Creative Commons Attribution 4.0 International License (http://creativecommons.org/licenses/by/4.0/), which permits use, sharing, adaptation, distribution and reproduction in any medium or format, as long as you give appropriate credit to the original author(s) and the source, provide a link to the Creative Commons license and indicate if changes were made.

The images or other third party material in this chapter are included in the chapter's Creative Commons license, unless indicated otherwise in a credit line to the material. If material is not included in the chapter's Creative Commons license and your intended use is not permitted by statutory regulation or exceeds the permitted use, you will need to obtain permission directly from the copyright holder.

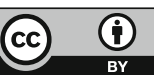

